\section{Loyalitas Kreativitas \\ Aldi Masyarakat Kreatif}

\title{
PERENCANAAN WAKTU DAN PERENCANAAN KEUANGAN IBU-IBU PKK DI KELURAHAN REMPOA, KECAMATAN CIPUTAT TIMUR, KOTA TANGERANG SELATAN
}

\author{
${ }^{1}$ Derita Qurbani*, ${ }^{2}$ Aria Aji Priyanto, ${ }^{3}$ Ali Zaenal Abidin, ${ }^{4}$ Sinta Sulistiani, ${ }^{5}$ Hendri \\ Prasetyo \\ Dosen Ekonomi Fakultas Ekonomi Universitas Pamulang \\ Email: dosen01582@unpam.ac.id, dosen01048@unpam.ac.id,dosen01876@unpam.ac.id \\ ,dosen00806@unpam.ac.id
}

\begin{abstract}
ABSTRAK
Waktu merupakan hal yang sangat penting, keberhasilan dalam kehidupan ditentukan oleh seberapa efektif kita dalam memanfaatkan waktu,Bagaiman waktu dibuat untuk mencapai tujuan tujuan yang ditentukan serta langka apa saja yang harus diperhatikan dalam pengelolaan waktu. Dalam perencanaan keuangan, bahwa bagaimana kita bisa memanfaatkan sumber daya yang ada untuk memenuhi kebutuhan dan bahkan beberapa ada yang bertujuan untuk mendapatkan keunytungan. Perencanaan keuangan diperlukan untuk persiapan agar kehidupan lebh sejahtera di masa depan. Adapun tujuan dari Pengabdian kepada Masyarakat (PKM) ini adalah untuk berbagi pengetahuan tentang bagaimana mengaplikasikan perencanaan waktu dan perencanaan keuangan pada Ibu-ibu PKK di Kelurahan Rempoa, Kecamatan Ciputat Timur, Kota Tangerang Selatan.

Dalam melaksanakan kegiatan PKM digunakan beberapa meode pelatihan, yaitu: 1) Metode Ceramah/Presentasi. Metode ceramah/presentasi dipilih untuk memberikan penjelasan tentang: a. Pengertian waktu dan pentingnya perencanaan waktu. b. Presentasi mengenai materi pengertian keuangan dan perencanaan keuangan; 2) Metode Tanya Jawab. Metode tanya jawab sangat penting bagi para peserta pelatihan. Metode ini memungkinkan ibu PKK menggali pengetahuan sebanyak-banyaknya tentang perencanaan waktu dan perencanaan keuangan; 3) Sharing Session Tentang mengoptimalkan pengelolaan waktu dan keuangan. Sharing session ini diberikan kepada para peserta pelatihan dalam memberikan masukan dan bimbingan untuk mempraktekan materi yang diperoleh. Harapannya, peserta pelatihan dapat menguasai materi pelatihan yang diterima dan dapat diaplikasikan dalam kehidupan sehari - hari.

Adapun hasil dari kegiatan Pengabdian kepada Masyarakat ini adalah perencanaan waktu dan perencanaan keuangan bagi rumah tangga ibu ibu PKK bagaimana memanfaat kan waktu sebaik baiknya dan merencanakan keuangan sesuai dengan kondisi kehidupannya untuk menghindari pemborosan dalam menigkatkan kualitas kehidupannya.Merencanakan waktu untuk mencapai tujuan kegiatan kegiatan yang menghasilkan serta merencanakan keuangan dengan proses yang berkesinambungan dan bersifat dinamis. Pada suatu saat, rencana tersebut dapat memerlukan penyesuaian
\end{abstract}

\section{Kata Kunci: Perencanaan waktu, Perencanaan Keuangan}

\section{ABSTRACT}

Time is very important, success in life is determined by how effective we are in utilizing time, how time is made to achieve the goals set and what are the scarcity that must be considered in managing time. In financial planning, that is how we can utilize the available resources to meet needs and some even have the aim to gain profit. Financial planning is needed to prepare for a better life in the future. The purpose of Community 
Loyalitas Kreativitas

Aldi Masyarakat Kreatif
P-ISSN 2722-2101, E-ISSN 2722-4201

Program Studi Ekonomi Manajemen Universitas Pamulang

Jurnal LOKABMAS Kreatif Vol. 01, No. 03, Hal. 69-80

Email:jurnalkreatif.manajemen@gmail.com

Service (PKM) is to share knowledge about how to apply time planning and financial planning to PKK women in Rempoa Village, Ciputat Timur District, South Tangerang City.

In carrying out PKM activities several training methods are used, namely: 1) Lecture / Presentation Method. The lecture / presentation method was chosen to provide an explanation of: a. Understanding time and the importance of time planning. $b$. Presentation on financial understanding and financial planning material; 2) Question and Answer Method. The question and answer method is very important for the trainees. This method allows PKK mothers to gain as much knowledge about time planning and financial planning; 3) Sharing Session About optimizing time and financial management. This sharing session is given to the training participants in providing input and guidance to practice the material obtained. It is hoped that the training participants can master the training material received and can be applied in daily life.

The results of this Community Service activity are time planning and financial planning for PKK housewives how to make the best use of time and financial planning in accordance with their living conditions to avoid waste in improving their quality of life. Planning for time to achieve the objectives of activities that produce and financial planning with a continuous and dynamic process. At some point, the plan can require adjustment

\section{Keywords: Time Planning, Financial Planning}

\section{PENDAHULUAN}

\subsection{Analisis}

Permasalahan

Perencanaan Waktu

Fungsi perencanaan dilakukan melalui tahapan-tahapan tertentu. Untuk menetapkan suatu rencana diperlukan waktu tertentu. Cepat atau lambat waktu yang diperlukan bergantung pada faktor-faktor yang dalam proses perencanaan tersebut, baik dari dalam maupun dari luar diri para perencana. Para Walaupun waktu dalam perencanaan hanyalah digunakan sebagai batasan untuk mencapai tujuan organisasi, namun faktor waktu tersebut sangat berpengaruh dan penting untuk diperhatikan dalam membuat dan menetapkan suatu perencanaan. Besarnya pengaruh waktu dalam perencanaan terutama dapat dirasakan dalam hal :
- Waktu sangat diperlukan untuk melaksanakan perencanaan efektif.

- Waktu sering dilakukan untuk melanjutkan setiap langkah perencanaan tanpa informasi lengkap tentang variabel-veriabel dan alternatif-alternatif, karena waktu diperlukan untuk mendapatkan data dan memperhitungkan semua kemungkinan.

- Jumlah atau rentang waktu yang akan dicakup dalam rencana harus dipertimbangkan.

Faktor waktu dalam perencanaan pada setiap tingkatan manajemen berbeda-beda. Semakin tinggi tingkatan manajemen akan membutuhkan waktu yang lebih lama dalam perencanaan. Demikian juga periode waktu berlakunya rencana yang 
Loyalitas Kreativitas

Aldi Masyarakat Kreatif
P-ISSN 2722-2101, E-ISSN 2722-4201

Program Studi Ekonomi Manajemen Universitas Pamulang

Jurnal LOKABMAS Kreatif Vol. 01, No. 03, Hal. 69-80

Email:jurnalkreatif.manajemen@gmail.com ditetapkan juga berbeda. Pada umumnya, pembagian periode perencanaan berdasarkan tingkat manajemen adalah sebagai berikut:

- Manajer puncak, membuat rencana-rencana jangka panjang antara 2 - 5 tahun atau lebih, contoh : rencana dalam menghadapi strategi persaingan perusahaan, rencana untuk menghasilkan suatu produk baru, dan lain sebagainya.

- Manajer menengah, membuat rencana-rencana jangka menengah antara beberapa bulan sampai 3 tahun, contoh : rencana dalam memperbaiki atau meninjau kembali jadwal produksi dan koordinasi, rencana untuk memanfaatkan para manajer lini pertama secara lebih baik, dan lain sebagainya.

- Manajer lini pertama, membuat rencana-rencana jangka pendek, bisa harian, bulanan, sampai satu tahun, contoh : rencana untuk mengimplementasikan

kebijakan, penugasan kerja, dan metode kerja baru, rencana untuk menaikkan efisiensi, dan lain sebagainya.

Sedangkan berdasarkan batasan waktu, pada umumnya rencana dapat dibedakan menjadi :

- Rencana jangka pendek (short range plans), mencakup berbagai rencana dari satu hari sampai satu tahun.
- Rencana jangka menengah (intermediate range plans), mempunyai rentagan waktu antara beberapa bulan sampai tiga tahun.

- Rencana jangka panjang (long range plans), meliputi kegiatan-kegiatan selama dua sampai lima tahun, dengan beberapa rencana yang diproyeksikan 25 tahun atau lebih di masa yang akan datang. Perencanaan jangka panjang biasanya berkenaan dengan perencanaan strategik.

Namun begitu, tetaplah dirasakan sulit untuk menentukan secara tepat suatu rencana dikatakan sebagai rencana jangka pendek, jangka menengah, atau jangka panjang. Hal ini disebabkan karena masing-masing perusahaan mempunyai tujuan yang berbeda, sehingga waktu yang ditetapkan untuk mencapai target tujuan dalam perencanaan juga berbeda. Selain itu, rencana juga dapat berubah dari jangka panjang menjadi jangka pendek sesuai dengan perjalanan waktu. sehingga batasan tentang waktu tersebut hanyalah sebagai pedoman kasar dalam perencanaan. Faktor waktu lainnya yang mempengaruhi perencanaan adalah seberapa sering rencana-rencana harus ditinjau kembali dan diperbaiki. Hal in tergantung pada sumber daya yang tersedia dan derajat ketetapan perencanaan manajemen. Hubungan yang sering dijumpai dalam praktek adalah semakin panjang jangka waktu suatu rencana, semakin panjang periode untuk peninjauan kembali dan perbaikannya. Demikian juga, semakin penting rencana terhadap 
Loyalitas Kreativitas

Aldi Masyarakat Kreatif
P-ISSN 2722-2101, E-ISSN 2722-4201

Program Studi Ekonomi Manajemen Universitas Pamulang

Jurnal LOKABMAS Kreatif Vol. 01, No. 03, Hal. 69-80

Email:jurnalkreatif.manajemen@gmail.com keberhasilan organisasi, maka rencana tersebut akan semakin sering diteliti dan perhatikan.

Perencanaan Keuangan

Semua orang punya tujuan finansial yang ingin dicapai seperti membayar hutang, menabung untuk beli rumah, memanfaatkan waktu untuk berlibur ke luar negeri atau hanya sekedar merasa tenang dengan kondisi finansial yang baik. Untuk tujuan-tujuan finansial apapun itu, Anda bekerja keras setiap harinya. Ngantor dari mulai pukul 8 pagi hingga 5 sore bahkan lembur sampai tengah malam pun rela Anda lakukan. Maka dari itu, perencanaan keuangan adalah langkah awal yang harus Anda lakukan untuk mencapai tujuan finansial yang Anda cita-citakan. Bayangkan jika Anda tak membuat perencanaan keuangan, di tengah kepenatan kerja dan jadwal yang ketat, Anda bisa terjebak pada gaya pengeluaran yang sangat berlebihan. Anda bergantung pada kartu kredit untuk membiayai gaya hidup Anda bahkan hingga overlimit, lalu Anda harus membayar bunga kartu kredit itu tiap bulannya. Belum lagi di usia Anda yang tak muda lagi nanti, Anda belum memiliki aset apa-apa seperti rumah ataupun mobil, misalnya. Sedangkan, tiap tahun inflasi terus meningkat, harga barang kebutuhan pokok juga meningkat sedangkan pendapatan yang Anda dapatkan dari hasil kerja masih sama. Sudah saatnya Anda mengubah rencana finansial Anda agar lebih sehat dan terukur. Paling tidak, Anda bisa mendapat gambaran diri Anda dalam beberapa waktu ke depan, dan mampu mandiri secara finansial.

Di Amerika Serikat, negara maju dengan kekuatan ekonomi super serta taraf hidup masyarakatnya yang tinggi, rupanya hampir 22 persen masyarakatnya mengaku tak memiliki rencana keuangan. Mereka juga mengaku tak punya gambaran jelas tentang pengeluaran mereka pada berbagai sektor seperti rumah, makanan dan hiburan. Sisanya 78 persen mengaku mereka tahu uang mereka dihabiskan dan dibelanjakan untuk apa saja, namun tak memiliki rencana keuangan. Itu di Amerika, dengan ekonomi negara maju. Bayangkan di Indonesia yang masih dalam katagori negara berkembang dengan perubahan kebijakan ekonomi yang fluktuatif serta nilai tukar yang lemah.

Tanpa perencanaan keuangan, gambaran finansial yang Anda alami akan kabur. lebih buruknya, Anda bisa terjebak pada gaya hidup yang overspending atau membelanjakan uang melebihi apa yang Anda butuhkan dan melebihi penghasilan Anda sendiri. Peribahasa umum mengatakan 'Besar pasak daripada tiang'. Overspending itu bisa jadi semakin buruk dengan kebiasaan Anda menggunakan kartu kredit secara tidak bertanggung jawab. Anda akan selalu bingung ataupun cemas atas keuangan Anda karena terlalu banyak hutang. Maka, perencanaan keuangan sangat penting untuk menumbuhkan rasa percaya diri dan kepastian atas masa depan Anda serta kehidupan yang Anda inginkan.

Lokasi yang akan dijadikan tempat PKM nanti di kelurahan rempoa dengan audiensi Ibu ibu PKK yang memang membutuhkan sharing dan pengetahuan tentan perencanaan waktu dan 
Loyalitas Kreativitas

Aldi Masyarakat Kreatif
P-ISSN 2722-2101, E-ISSN 2722-4201

Program Studi Ekonomi Manajemen Universitas Pamulang

Jurnal LOKABMAS Kreatif Vol. 01, No. 03, Hal. 69-80

Email:jurnalkreatif.manajemen@gmail.com perencanaan keuangan untuk kehidupan yang lebih baik.

Maka dari itu kami mengangkat tema "Perencanaan Waktu dan Perencanaan Keuangan Ibu-Ibu PKK Di Kelurahan Rempoa, Kecamatan Ciputat Timur, Kota Tangerang Selatan".

\section{RUMUSAN MASALAH}

Sesuai dengan latar belakang dan permasalahan yang dihadapi oleh Ibu PKKDi Kelurahan Rempoa, Kecamatan Ciputat Timur, Kota Tangerang Selatan. Adapun rumusan masalah dalam PKM ini adalah.

Dalam Perencanaan Waktu :

1. Waktu sangat diperlukan untuk melaksanakan perencanaan efektif. Bagaimana melakukannya?

2. Bagaiman waktu sering dilakukan untuk melanjutkan setiap langkah perencanaan tanpa informasi lengkap tentang variabel-veriabel dan alternatifalternatif, karena waktu diperlukan untuk mendapatkan data dan memperhitungkan semua kemungkinan?

3. Bagaimana jumlah atau rentang waktu yang akan dicakup dalam rencana harus dipertimbangkan?

4. Bagaimana membuat rencana jangka pendek (short range plans), mencakup berbagai rencana dari satu hari sampai satu tahun.

5. Bagaimana membuat Rencana jangka menengah (intermediate range plans), mempunyai rentagan waktu antara beberapa bulan sampai tiga tahun.

6. Bagaimana membuat rencana jangka panjang (long range plans), meliputi kegiatan- kegiatan selama dua sampai lima tahun, dengan beberapa rencana yang diproyeksikan 25 tahun atau lebih di masa yang akan datang. Perencanaan jangka panjang biasanya berkenaan dengan perencanaan strategik.

Dalam Perencanaan Keuangan :

1. Bagaiamana menyikapi minimnya pengetahuan seputar finansial

2. Bagaimana mengelola hutang karena memiliki banyak hutang

3. Bagaimana menyikapi tekanan gaya hidup

4. Bagaimana mengelola keuangan dengan adanya inflasi

5. Bagaimana menggambarkan kondisi keuangan anda saat ini

6. Bagaimana mengalokasikan dana lebih jelas, pengalokasian pendapatan untuk belanja kebutuhan, membayar tagihan, investasi dan simpanan

7. memotivasi untuk melakukan perencanaan keuangan

\section{TUJUAN PELAKSANAAN}

Setiap kegiatan yang dilakukan harus memiliki tujuan yang jelas, supaya tidak salah sasaran. Adapun tujuan pada PKM ini adalah:

1. Untuk mengetahui cara merencanakan waktu pada Ibuibu PKK di Kelurahan Rempoa, Kecamatan Ciputat Timur, Kota Tangerang Selatan.

2. Untuk mengetahui cara merencanakan keuangan pada Ibu-ibu PKK di Kelurahan Rempoa, Kecamatan Ciputat 


\section{Loyalitas Kreativitas \\ Aldi Masyarakat Kreatif}

P-ISSN 2722-2101, E-ISSN 2722-4201

Program Studi Ekonomi Manajemen Universitas Pamulang

Jurnal LOKABMAS Kreatif Vol. 01, No. 03, Hal. 69-80

Email:jurnalkreatif.manajemen@gmail.com
Timur, Kota Tangerang Selatan

3. Untuk mengetahui pengelolaan waktu yang efektif bagi Ibuibu PKK di Kelurahan Rempoa, Kecamatan Ciputat Timur, Kota Tangerang Selatan.

4. Untuk mengetahui pengelolaan keuangan bagi Ibu-ibu PKK di Kelurahan Rempoa, Kecamatan Ciputat Timur, Kota Tangerang Selatan.

\section{TINJAUAN PUSTAKA}

II.

\subsection{Pengertian Waktu dan Manfaatnya \\ Waktu yang kita punya} adalah 24 jam dalam sehari untuk bisa mempergunakannya dengan tepat dan efisien menurut kebutuhan masing- masing individu. Hanya saja tidak semua orang mengerti atau menggunakan waktu yang mereka punya dengan sebaik mungkin juga bahkan lalai untuk memahami konsep waktu yang berharga. Karena inilah adanya istilah, pemberdayaan dan penerapan time management atau manajemen waktu Manajemen waktu merupakan suatu guideline atau panduan yang terdiri dari perencanaan, pengendalian dan struktural cara menggunakan terhadap seberapa banyak waktu yang kita pakai dan gunakan untuk menyelesaikan suatu pekerjaan. Seorang individu harus memahami nilai waktu baginya untuk berhasil dalam aspek kehidupan dan pekerjaan. Orang yang membuang waktu adalah orang yang gagal dalam mengatur pola hidup dan identittas mereka sendiri. Pengelolaan waktu yang baik dapat membantu Anda untuk meningkatkan kinerja dan karier
Anda. Pengorganisasian setiap hari membantu Anda menyelesaikan pekerjaan tepat waktu, tetap dapat terlibat selama rapat penting dan memberi Anda ruang waktu untuk menjadi kreatif serta proaktif dalam tugas- tugas Anda. Memiliki keterampilan manajemen waktu yang kuat pada akhirnya dapat mengarahkan Anda kepada pencapaian tujuan utama dan memajukan posisi Anda. Manajemen waktu adalah proses perencanaan dan pengendalian secara sadar terhadap waktu yang dihabiskan untuk kegiatan tertentu, terutama untuk meningkatkan efektivitas, efisiensi, dan produktivitas. Cara ini juga melibatkan tindakan menyeimbangkan berbagai tuntutan terhadap seseorang yang berkaitan dengan pekerjaan, kehidupan sosial, keluarga, hobi, minat pribadi dan komitmen dengan keterbatasan waktu. Menggunakan waktu dengan efektif memberi seseorang kelebihan juga pilihan untuk mengelola kegiatan menurut keputusan dan kebijaksanaan mereka sendiri. Manajemen waktu biasanya selalu didukung oleh berbagai keterampilan, alat serta teknik yang digunakan untuk mengatur waktu ketika menyelesaikan tugas, proyek dan tujuan tertentu sesuai dengan tanggal deadline (tempoh waktu).

Mulanya manajemen waktu disebut hanya sebatas kegiatan bisnis atau kerja, tetapi istilah ini kemudian diperluas dengan memasukkan kegiatan- kegiatan pribadi. Sistem manajemen waktu adalah kombinasi dari proses, alat, teknik dan metode yang dirancang sedemikian rupa. Manajemen waktu telah menjadi kebutuhan dasar setiap pengembangan proyek 
Loyalitas Kreativitas

Aldi Masyarakat Kreatif
P-ISSN 2722-2101, E-ISSN 2722-4201

Program Studi Ekonomi Manajemen Universitas Pamulang

Jurnal LOKABMAS Kreatif Vol. 01, No. 03, Hal. 69-80

Email:jurnalkreatif.manajemen@gmail.com sebagai penentu waktu dan ruang lingkup penyelesaian proyek tersebut. Selain itu penting juga untuk memahami bahwa perbedaan teknis dan struktural dalam manajemen waktu ada karena variasi dalam konsep budaya penggunaan waktu.

\section{Manfaat dan fungsi manajemen waktu}

Kemampuan seseorang dalam mengatur waktunya secara efektif akan sangat berperan penting dalam segala hal karena penggunaan waktu yang baik akan membawa pada peningkatan efisiensi serta produktivitas yang sesuai target dengan lebih sedikit stres ataupun beban yang tidak penting. Berikut ini adalah manfaat dalam manajemen waktu yang benar :

\section{- Meningkatkan} produktivitas efisiensi dalam pekerjaan

Sebuah manajemen waktu yang baik akan mampu membawa fokus dan perhatian Anda pada target pencapaian. Anda tidak lagi kebingungan dalam menentukan prioritas jika Anda mempunyai manajemen waktu yang tersusun baik.

- Meningkatkan Kepuasan Pekerjaan dan Peningkatan Peluang

Pekerjaan yang selesai tepat waktu dan sesuai tentu akan menambah rasa puas secara pribadi dan memberi Anda lebih banyak kelebihan waktu serta peluang untuk mengeksplorasi peluangpeluang lain yang ada.

- Mengurangi Kadar Stress dan Tekanan

Dengan tercapainya target pekerjaan dan ketepatan waktu dapat mengurangi beban kerja, stress juga tekanan. Disamping itu Anda juga berpeluang untuk merevisi pekerjaan yang Anda rasa kurang memadai dengan lebih cermat tanpa khawatir.

- Mencapai Target dan Tujuan

Target yang diinginkan akan lebih cepat terealisasi dan sasaran yang hendak dituju menjadi jelas serta terselesaikan dalam waktu yang lebih singkat.

\subsection{Pengertian Keuangan dan} Manfaatnya

Pengertian keuangan menurut Gitman (2012:4) adalah sebagai berikut

"Finance can be defined as the science and art of managing money".

Dari definisi tersebut maka dapat dikembangkan bahwa keuangan sebagai seni berarti

melibatkan keahlian dan pengalaman, sedangkan sebagai ilmu berarti melibatkan prinsip prinsip, konsep, teori, proposi dan model yang ada dalam ilmu keuangan.

Sedangkan menurut Sundjaja dan Barlian (2002:34 ) :

"Keuangan merupakan ilmu dan seni dalam mengelola uang yang 
Loyalitas Kreativitas

Aldi Masyarakat Kreatif
P-ISSN 2722-2101, E-ISSN 2722-4201

Program Studi Ekonomi Manajemen Universitas Pamulang

Jurnal LOKABMAS Kreatif Vol. 01, No. 03, Hal. 69-80

Email:jurnalkreatif.manajemen@gmail.com mempengaruhi kehidupan setiap orang dan setiap organisasi. Keuangan berhubungan dengan proses, lembaga, pasar, dan instrumen yang terlibat dalam transfer uang diantara individu maupun antara bisnis dan pemerintah".

Kemudian menurut pendapat Le Countre dan Hasenack yang disadur oleh Bambang Riyanto adalah

"Meliputi keseluruhan usaha untuk mempersiapkan dan mengatur penarikan dan

penggunaan dana dimana disini termasuk perencanaan dan pelaksanaannya".

Berdasarkan pendapat para ahli diatas maka dapat ditunjukan bahwa keuangan adalah ilmu atau seni dalam mengelola uang yang meliputi keseluruhan usaha untuk mempersiapkan dan mengatur penarikan dan pengun aan dana berdasarkan keahlian dan pengalaman, prinsip- prinsip, konsep, teori, proporsi dan model

Pada akhirnya nanti, seseorang berharap bisa mencapai tujuan akhir dari perencanaan keuangan yaitu kebebasan finansial (financial freedom), yang dapat diartikan : bebas dari hutang, tersedianya arus penghasilan dari investasi yang telah dilakukannya, serta terproteksi secara finansial dari risiko apapun yang mungkin terjadi.

\section{HASIL DAN PEMBAHASAN}

Sumber: dokumentasi saat pelaksanaan PKM.

\subsection{Cara merencanakan waktu pada Ibu-ibu PKK di Kelurahan}

\section{Rempoa, Kecamatan Ciputat Timur, Kota Tangerang Selatan.}

Adapun strategi Perencanaan Waktu adalah sebagai berikut:

1. Cukupkan waktu tidur antara 6 - 8 jam/per hari;

2. Upayakan jadwal aktivitas anda berlangsung antara pukul 06.00 - 22.00 WIB;

3. Tiap minggu jadwal anda berisi 4 kelompok aktivitas dalam uraian nomor 3 di atas;

4. Jadwalkan bahwa waktu belajar mandiri anda minimal 20 jam/per minggu (di luar waktu kuliah di kelas);

5. Rencanakan waktu belajar mandiri maksimum 10 jam/per hari;

6. Rencanakan waktu belajar mandiri untuk setiap subyek atau topik maksimum 5 jam/per hari;

7. Selang-seling topik belajar mandiri secara teratur jika anda misalnya memutuskan bahwa dari jam 07.00 hingga 13.00 adalah waktu belajar mandiri (maksudnya anda tidak menghabiskan waktu 6 jam hanya untuk belajar satu topik);

8. Ketahui diri anda apakah sebagai 'morning person', 'night owl person', atau 'late afternoon person' untuk memastikan bahwa jadwal tersebut sesuai dengan irama kerja dan 'jam biologis' anda;

9. Luangkan waktu untuk istirahat sejenak ditengah waktu belajar (misal, istirahat tidak lebih 10 menit dari setiap jam);

10. Latih dan biasakan diri anda untuk mengerjakan sesuatu cukup sekali, alias hindari kebiasaan untuk mengulangulang. Misal, membaca teks tentang suatu topic sedapat 
Loyalitas Kreativitas

Aldi Masyarakat Kreatif
P-ISSN 2722-2101, E-ISSN 2722-4201

Program Studi Ekonomi Manajemen Universitas Pamulang

Jurnal LOKABMAS Kreatif Vol. 01, No. 03, Hal. 69-80

Email:jurnalkreatif.manajemen@gmail.com mungkin cukup 1 kali tetapi dengan memastikan anda paham dan ingat apa isinya. Hindari mitos bahwa untuk dapat memahami isi sebuah bacaan, anda harus membacanya 2-3 kali.

11. Belajar untuk focus atau konsentrasi, tanpa jeda untuk waktu minimal 15-20 menit; kemudian ditingkatkan menjadi focus selama 30-50 menit tanpa jeda. Hal ini diperlukan sekali terutama untuk membantu anda mendengarkan dosen menjelaskan di kelas, mencatat, membaca, dan menulis. Ingat, membaca dan menulis akademik membutuhkan waktu lebih panjang disbanding anda menulis surat biasa, membaca majalah, komik, atau apalagi menulis email, pesan elektronik, twitter atau sejenisnya.

12. Biasakan untuk melakukan halhal kecil dan 'remeh atau ringan' di sela-sela waktu istirahat atau ketika anda sedang menunggu sesuatu. Misal, merespon pesan elektronik dapat dilakukan hanya ketika anda istirahat atau ketika anda menunggu untuk bertemu dokter, dosen, mengantri di loket, atau ketika sedang di dalam angkot (tapi, awas dengan telepon seluler anda karena melakukan ini di dalam angkot juga potensial mengundang orang jahat untuk mengganggu anda);

13. Belajar dan biasakan diri untuk berani menolak ajakan atau mengatakan 'tidak' pada teman, sahabat, sanak famili ketika mereka mengundang atau mengajak melakukan satu kegiatan tertentu yang dapat mengacaukan manajemen waktu anda. Demikian pula untuk menolak keluar rumah menjelang hari ujian; atau ajakan untuk melakukan beberapa komitmen secara bersamaan;

\subsection{Cara merencanakan keuangan pada Ibu-ibu PKK di Kelurahan Rempoa, Kecamatan Ciputat Timur, Kota Tangerang Selatan.}

Adapun strategi Perencanaan Keuangan adalah sebagai berikut:

1. Soal mengelola keuangan. Kenapa ketika sakit berkunjung ke dokter, karena tidak paham soal ilmu kedokteran, Anda butuh saran ahli mengenai cara penyembuhan yang efisien dan efektif. Karena tidak tahu mengelola keuangan, Anda memanfaatkan perencana keuangan untuk memberikan saran bagaimana menata keuangan keluarga. Perencana keuangan memiliki pendidikan dan pengalaman dalam menangani masalah keuangan. Misalnya, bagaimana mempersiapkan dana pendidikan anak, mereka tahu cara yang paling efisien dan efektif untuk mencapai tujuan tersebut. Bukankah bisa belajar sendiri? Bisa saja, namun tantangannya adalah waktu dan kemampuan untuk belajar.

2. Memberikan potret objektif kondisi keuangan. Tidak mudah bersikap objektif ketika menghadapi masalah keuangan. Dalam masalah lain, kita mungkin bisa berpikir jernih dan mengambil keputusan yang rasional. Tetapi seringnya tidak, ketika menyangkut keuangan keluarga. Banyak yang denial, misalnya keuangan tidak 
Loyalitas Kreativitas

Aldi Masyarakat Kreatif
P-ISSN 2722-2101, E-ISSN 2722-4201

Program Studi Ekonomi Manajemen Universitas Pamulang

Jurnal LOKABMAS Kreatif Vol. 01, No. 03, Hal. 69-80

Email:jurnalkreatif.manajemen@gmail.com mendukung tetapi tetap mengirim anak ke sekolah internasional yang biayanya selangit. Itu makanya, banyak kelas menengah yang berpenghasilan lebih dari cukup, tetapi punya hutang kartu kredit yang tidak terkendali. Karena tidak ada hubungan emosional dengan kekayaan Anda, perencana keuangan dapat memberikan analisa yang objektif, terang benderang. Misalnya, perencana akan melakukan diagnostik ( financial checkup). Semua data keuangan diminta, diinput dan dikalkulasi, kemudian mereka menganalisa apakah Anda keuangan sehat atau tidak. Dimana masalahnya akan terpampang dengan gamblang. Semuanya objektif, berdasarkan angka serta hitung-hitungan.

3. Merealisasikan rencana keuangan. Rencana tanpa realisasi akan percuma, sia sia, macan kertas. Perencana hadir menuangkan rencana ke dalam langkah konkrit implementasi.Mereka berupaya Anda patuh dan dispilin mengikuti langkah - langkah yang sudah ditetapkan dalam rencana tersebut. Dari obrolan dengan salah satu konsultan, misalnya, saya tahu bahwa perencana keuangan memiliki orang - orang yang tugasnya mengingatkan Anda setiap bulan untuk melakukan investasi sesuai rencana . Mereka juga memantau secara rutin antara hasil dan tujuan di dalam rencana. Jika terjadi ketidakasesuaian, segera dilakukan kajian dan, jika perlu, rencana direvisi.
4. Mencarikan produk keuangan yang cocok. Ada banyak produk keuangan dijual di pasar. Jumlahnya yang banyak saja sudah membuat pusing, apalagi produk dijual lewat berbagai strategi promosi yang agresif. Mau pilih yang mana? Akhirnya sering terjadi, karena bingung, kita memilih produk yang paling menarik promosinya atau yang dijual oleh kerabat dekat yang diambil karena rasa tidak enak, sementara sangat mungkin itu bukan pilihan yang tepat. Karena berkutat di dunia keuangan, perencana keuangan paham segala produk serta melakukan riset dan mengumpulkan informasi secara rutin

\section{KESIMPULAN DAN SARAN \\ III.}

\subsection{Kesimpulan}

Fungsi perencanaan dilakukan melalui tahapan-tahapan tertentu. Untuk menetapkan suatu rencana diperlukan waktu tertentu. Cepat atau lambat waktu yang diperlukan bergantung pada faktor-faktor yang dalam proses perencanaan tersebut, baik dari dalam maupun dari luar diri para perencana. Walaupun waktu dalam perencanaan hanyalah digunakan sebagai batasan untuk mencapai tujuan organisasi, namun faktor waktu tersebut sangat berpengaruh dan penting untuk diperhatikan dalam membuat dan menetapkan suatu perencanaan. Besarnya pengaruh waktu dalam perencanaan terutama dapat dirasakan dalam hal waktu sangat diperlukan untuk melaksanakan perencanaan efektif, waktu sering dilakukan untuk melanjutkan setiap langkah perencanaan tanpa 
Loyalitas Kreativitas

Aldi Masyarakat Kreatif
P-ISSN 2722-2101, E-ISSN 2722-4201

Program Studi Ekonomi Manajemen Universitas Pamulang

Jurnal LOKABMAS Kreatif Vol. 01, No. 03, Hal. 69-80

Email:jurnalkreatif.manajemen@gmail.com informasi lengkap tentang variabel-veriabel dan alternatifalternatif, karena waktu diperlukan untuk mendapatkan data dan memperhitungkan semua kemungkinan. Jumlah atau rentang waktu yang akan dicakup dalam rencana harus dipertimbangkan.

Dalam menyusun perencanaan keuangan, seseorang akan dipengaruhi oleh kondisi (live event) yang sedang dialaminya sehingga dengan demikian perencanaan keuangan akan bersifat spesifik. Perencanaan keuangan juga merupakan suatu proses yang berkesinambungan dan bersifat dinamis. Pada suatu saat, rencana tersebut dapat memerlukan penyesuaian. Berikut merupakan beberapa kondisi atau kejadian yang dapat mempengaruhi perencanaan keuangan seseorang : Status perkawinannya (belum menikah atau sudah menikah) Kondisi pekerjaan (sudah memiliki pekerjaan tetap atau belum) Usianya (umur yang semakin bertambah), Kondisi keluarganya (jumlah anggota keluarga yang manjadi tanggungan), Kondisi perekonomian

(kemudahan dalam mencari pekerjaan dan penghasilan) Tingkat pendidikannya (tingkat pendidikan mempengaruhi penghasilan), serta, Kondisi kesehatannya (mempengaruhi biaya dan kelangsungan dari pendapatan). Perubahan pada salah satu atau beberapa kondisi di atas dapat mempengaruhi perencanaan keuangan yang sudah dibuat seseorang atau keluarga. Sehingga seringkali perencanaan keuangan seseorang harus disusun kembali (bersifat dinamis).

\subsection{Saran}

Adapun saran bahwa dalam Kegiatan ini bagaimana memberikan motivasi agar ibu ibu PKK dapat memahami implementasi perencanaan waktu serta perencanaan keuangan secara mendalam. bahwa dengan melakukan perencanaan waktu dan perencanaan keuangan secara bersama dapat meningkatkan kualitas hidup yang dapat menjamin kehidupan anak -anak mereka.

\section{DAFTAR PUSTAKA}

Dharma, Agus. 2004. Kegiatan Manajemen Waktu. PT. Bumi Aksara

Drucker dalam Timpe.2002. Manajemen Waktu Menurut Para Ahli. Jakarta: PT. Gramedia Pustaka Utama.

Analisis Kinerja Keuangan dan Perencanaan Keuangan Perusahaan.Cetakan kedua.PT Gramedia Pustaka Umum

Antonius, (2014). Time Management : Menggunakan Waktu Secara Efektif dan Efisien. Jurnal Humaniora. Vol 5. No 2

Elburdah, R. P., \& Oktrima, B. (2020). PENGARUH COMMUNITY OF PRACTICE PADA IMPLEMENTASI KNOWLEDGE MANAGEMENT PADA KANTOR KELURAHAN

REMPOA. JURNAL LOKABMAS KREATIF, 1(2), 11-15.

Sandra, K. I. dan Djalali M. A. Manajemen Waktu, Efikasi-Diri dan Prokrastinasi. Jurnal Psikologi Indonesia Vol 2 No 3 Hal 217-222 September 2013

Wibowo. (2013). Perilaku Dalam Organisasi. Jakarta: PT. Rajagrafindo Persada 


\section{Loyalitas Kreativitas \\ Aldi Masyarakat Kreatif}

P-ISSN 2722-2101, E-ISSN 2722-4201

Program Studi Ekonomi Manajemen Universitas Pamulang Jurnal LOKABMAS Kreatif Vol. 01, No. 03, Hal. 69-80

Email:jurnalkreatif.manajemen@gmail.com
Agnes, Sawir.(2015). Analisa Kinerja Keuangan dan Perencanaan keauangan. Perusahaan, Jakarta : PT. Gramedia Pustaka Utama.

Harahap, Sofyan Syafri.(2011). Analisis Kritis Atas Laporan Keuangan.Jakarta:PT Grafindo Perkasa, Hal 53

Pasaribu, V. L. D., Susanti, F., \& Hartuti, E. T. K. (2019). Memotivasi Siswa dan Siswi SMK Letris Indonesia di Dalam Menentukan Pilihan Untuk Melanjutkan Pendidikan Atau Bekerja Setelah Lulus Sekolah. Jurnal Pengabdian Dharma Laksana, 1(2), 161-172.

Pasaribu, V. L. D., Elburdah, R. P., Sudarso, E., \& Fauziah, G. (2020). PENGGUNAAN MANAJEMEN WAKTU TERHADAP PENINGKATAN PRESTASI BELAJAR DI SMP ARAISIYAH. Jurnal ABDIMAS Tri Dharma Manajemen, 1(1).

Pasaribu, V. L. D., Agrasadya, A., Shabrina, N., \& Krisnaldy, K. (2020). MENJADI ENTERPRENEUR MUDA YANG MEMILIKI JIWA LEADERSHIP UNTUK MENGHADAPI MASA DEPAN. Abdi Laksana, 1(1).

Pasaribu, V. L. D., Sulaiman, S., Sutiman, S., Thaharudin, T., \& Purnomo, B. Y. (2020). PENGENALAN LETAK POSYANDU TERDEKAT DIKELURAHAN PISANGAN DENGAN MANAJEMEN PEMASARAN REVOLUSI 4.0 UNTUK MENINGKATKAN PENGETAHUAN MASYARAKAT LETAK DAN FUNGSI POSYANDU TERDEKAT PADA KELURAHAN PISANGAN. DEDIKASI PKM, 1(1), 105-110.

Priadi, A., Pasaribu, V. L. D., Virby, S., Sairin, S., \& Wardani, W. G. (2020). PENGUATAN EKONOMI KREATIF BERBASIS SUMBER DAYA DESA DIKELURAHAN REMPOA. Abdi Laksana, 1(3), 356-358.

Sutrisno. (2015). Manajemen Keuangan Teori, Konsep dan Aplikasi. Yogyakarta: EKONISIA
Zarkasyi, Wahyudin. (2008). Good Corporate Governance.Bandung:Alfabeta

\section{DOKUMENTASI FOTO KEGIATAN}
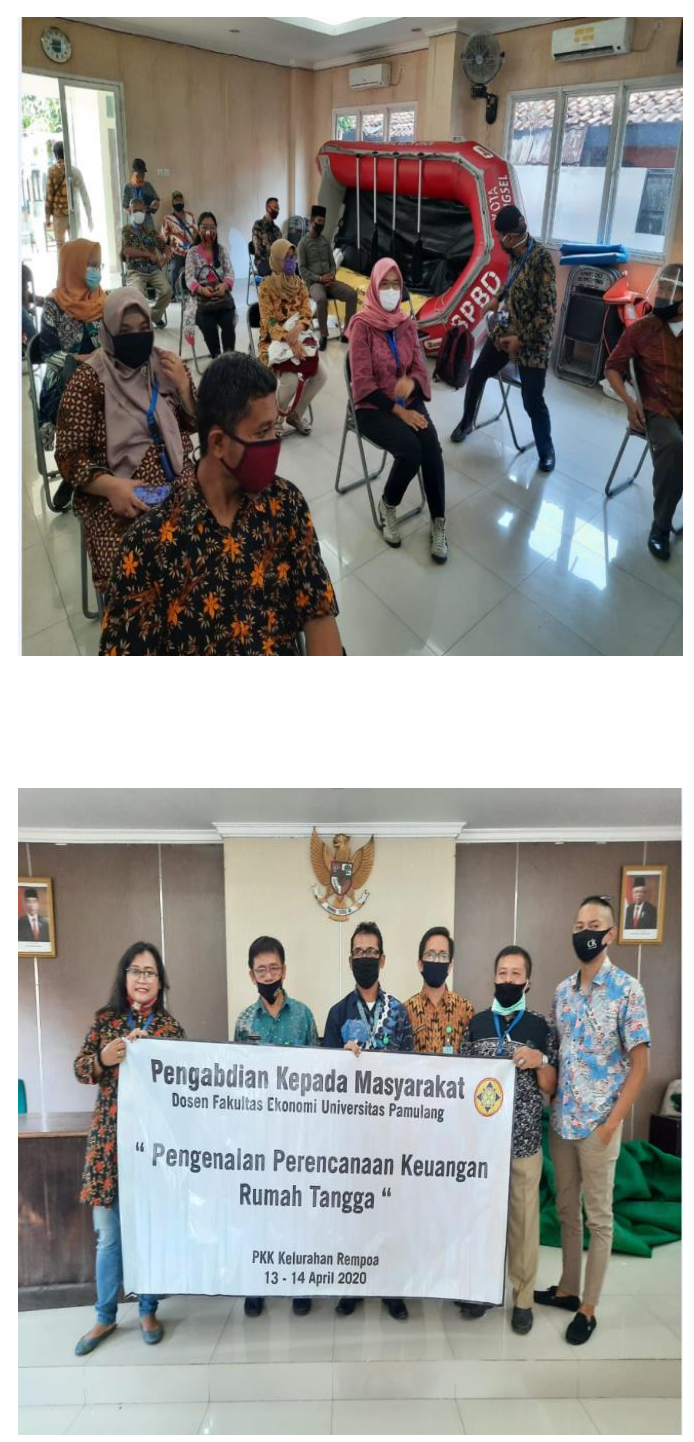